\title{
Inquiry Based Method and Student Academic Achievement in Secondary School Home Economics
}

\author{
Ifeanyi- Uche, U.P \\ School of Agriculture/Home Economics \\ Federal College of Education(Technical), Umunze-Anambra State, Nigeria \\ Ejabukwa Chima \\ School of Agriculture/Home Economics \\ Federal College of Education(Technical), Umunze-Anambra State, Nigeria
}

\section{Doi:10.5901/jesr.2013.v3n4p109}

\begin{abstract}
The study sought to find out the effect of inquiry based method on academic achievement of secondary school students in Home Economics. The study covered the secondary schools in Orumba South Local Government Area of Anambra State. Quasi-experiment design was the design used. Two study groups were randomly sampled from the 15 schools in the Local Government Area and assigned to experimental and control groups respectively. The experimental groups was taught with inquiry based method while the control group was taught using lecture method. A thirty five items Home Economics Achievement test developed by the researcher and validated by researchers colleagues was used to asses the subject achievement. Data collected were analyzed using percentage, mean and t-test statistics. The findings revealed that the experimental group (inquiry based method) achieved significantly higher than the control group (lecture method). Based on the findings, it was recommended that inquiry based method should be employed in teaching Home Economics.
\end{abstract}

\section{Introduction}

One of the principles of education in Nigeria is to equip every citizen with such knowledge, skills, attitudes and values that will enable him derive maximum benefits from his membership of society, have a fulfilling life and contribute towards the development and welfare of the community (FRN, 2004). Unfortunately academic achievement of Nigerian students in school subjects including Home Economics at secondary school level has remained poor over the years (Obika 2005). This could be as a result of poor mastery of the subject matter which occurs as a result of poor method of teaching. Retting and Canady (1996) reported that in schools where active learning methods prevail, the students demonstrated significantly higher achievement as measured by the National Assessment of educational progress.

Hall (1990) stated that teachers in these schools offer students challenging, interesting activities and rich materials for learning that foster thinking, creativity and production. They make available a variety of pathways to learning that accommodate different intelligent and learning styles, they allow students to make choice and contribute to some of their learning experiences and they use methods and engage students in hands on learning. Their instruction focuses on reasoning and problem soling. 
Inquiry-based instruction is a student-centered and teacher guided instructional approach that engage students in investigating real world questions that they choose within a broad thematic frame work. Inquire based instruction complements traditional instruction by providing a vehicle extending and applying the learning of students in a way that connects with their interests within a broad thematic frame work Njoku (2004) stated that inquire based learning is primarily a pedagogical method developed during the discovery learning movement of the 1960s as response to traditional forms of instruction. The students use the inquiring process to develop expiations from their observations by integrating what they already know with what they have learned. They learn concepts in Home Economics and skills and how to solve problems using practical approach. Inquiry based learning require the student to do more than just report on a topic. The student must go beyond the simple memorization of facts and regurgitation of information and into the realm of creating new and deeper understanding through identification and subsequent application of solutions to a specific topic. I ts efficacy in enhancing students achievement in home economics in comparison with that of the conventional lecture method is the focus of the study.

\section{Statement of the Problem}

The high rate of failure in Home economics in secondary schools shows that teaching and learning in these subject have been teacher centred instead of student-centred. Educators are seeking for alternative ways to teach home economics so as to change the situation. The problem is how can inquiry method of teaching improve students academic achievement in Home economics in secondary schools.

\section{Purpose of the Study}

The objective of the study are

1. To compare the mean percentage score of students taught Home economics using inquiry based teaching method and those taught using lecture method.

2. To compare the mean achievement scores of students taught through inquiry based method and those taught using lecture method.

\section{Research Questions}

What are the mean percentage scores of students taught Home Economics using inquiry based teaching method and those taught using lecture method.

\section{Hypothesis}

The following Null hypothesis tested at 0.05 level of significance guided the study.

$\mathrm{H}_{01}$ : There will be no significant difference between the academic achievement of students taught Home economics using inquiry based teaching and that of those taught using lecture method based on their mean percentage scores in Home economics achievement test.

\section{Methodology and Procedure}

Design A quasi experimental research design was employed using two groups experimental and control.

Population The population of the study comprises of all the secondary schools in Orumba South Local Government Area (Source: Statistics unit, Orumba South Headquarters Umunze). 
Sample and Sampling Techniques: Simple random sampling was in selecting four secondary schools. From each of the four schools, 20 SS I Home economics students were selected. This amount to a total of eighty students from the four schools representing the sample of the study. These students were randomly assigned to two groups (treatment and control) groups.

\section{Instrument}

An instrument known as Home economics achievement. Test (HAT) was used for data collection. The Home economics Achievement test (HAT) developed by the researchers is a thirty five item multiple choice achievement test on the identified difficult - to-learn Home Economics topics.

\section{Validation and reliability of Instrument}

The face validity of the instrument was established by giving it to three exparts in Home economics department of F.C.E (T), Umunze and one Home economics teacher in one of the sample schools. Reliability coefficients of 0.89 were obtained using person product moment correlation.

\section{Experimental procedure}

The Home economics teachers in these schools were used in administering the instrument. The inquiry based method was used by the experiment group whereas the lecture method was used for the control group. The topics were taught for a total of five periods of 40 minutes each per group.

\section{Method of data Analysis}

The score of each of the subjects were converted to simple percentage. These were summed up and the mean percentage score computed for each of the two groups t-test statistics was used to test the hypothesis.

\section{Results}

The results of the study are presented in the table below,

Research Question I: What are the mean percentage scores of pupils taught Home economics using inquiry based method and that of those taught using lecture method.

Table I: Mean percentage scores of students in experimental and control groups.

\begin{tabular}{|l|l|l|}
\hline Group & $\mathrm{N}$ & Mean $\overline{(x)}$ \\
\hline Experimental group (inquiry Based method) & 40 & 53.5 \\
\hline Control group (lecture method) & 40 & 25.3 \\
\hline
\end{tabular}

Data in table I showed that students taught with inquiry based method had percentage mean score of 53.5, those taught with lecture method had percentage mean score of 25.3. The experimental group therefore performed better than the control group.

\section{Hypothesis}

There will be no significant difference between the academic achievement of students taught Home economics using inquiry based method and those taught with lecture method. 
Table 2: t-test analysis of mean achievement scores of students taught using inquiry Based Teaching method and those taught using lecture method.

\begin{tabular}{|l|c|c|c|c|c|c|c|c|}
\hline $\begin{array}{l}\text { Teaching } \\
\text { method }\end{array}$ & Mean & SD & $\mathrm{N}$ & Staff & Std & t- cal & t- crit & Decision \\
\cline { 1 - 8 } \\
$\begin{array}{l}\text { Inquiry } \\
\text { method }\end{array}$ & 53.5 & 9.54 & 40 & 78 & 1.65 & 17.1 & 1.96 & $\begin{array}{c}\text { Reject } \\
\mathrm{H}_{01}\end{array}$ \\
\hline $\begin{array}{l}\text { Lecture } \\
\text { method }\end{array}$ & 25.3 & 4.23 & 40 & & & & \\
\hline
\end{tabular}

From the table 2 above the t-test statistics reveled that t-calculated (17.1) is greater than the tcritical (1.96) at 0.05 level of significance, the null hypothesis is therefore rejected. This means that the students taught with inquiry based teaching method perform better than those taught with lecture method in Home economics

\section{Discussion}

The findings of research question I revealed that the instructional method has a significant main effect on students achievement in Home economics. Ajayi (2002) stated inquiry is important in the generation and transmission of knowledge. The relative superiority of the inquiry based method over the lecture method in enhancing students achievement could be attributed to the fact that as instructional strategy, the inquiry based method helps students to learn to investigate and construct ideas.

Findings in Hypothesis showed that there is significant difference between the mean achievement scores of students taught with inquiry based method and those taught with lecture method. The findings are in line with what Ezeugwu (2007) stated that teachers instructional method can greatly influence students achievement of acquisition of skills.

\section{Recommendations}

Based on the findings, the following are recommended.

1. The use of inquiring based method should be given emphasis in the curriculum of preservice teachers of Home economics

2. Home economics teachers should be trained and retrained on the use of inquiry based method in teaching.

3. There should be proper provisions of facilities which are necessary for effective inquiring strategies.

\section{Conclusion}

Based on the results obtained in the study, it is therefore concluded that inquiry based method enhances effective understanding and comprehension of Home economics concepts and skill acquisition, therefore it should be used in teaching secondary school students.

\section{References}

Ajayi, K. (2002) Teaching and administering in the Nigeria educational system. Abeokuta: Research and publishers committee.

Ezeugwu, E.N (2007). Effects of self Regulated and lecture method on students achievement in Biology. Nigerian Journal of functional Education 5 (1) 82-91.

Federal Republic of Nigeria (2004). National Policy on Education. Lagos: NERDC Press. 
Hall, D (1990). A comparison of a biological science curriculum study laboratory on student achievement at two private liberal arts colleges. Journal of Research in science Teaching 27: 625636.

Njoku, Z.C (2004). Fostering the application of science education research findings in Nigeria Classrooms, strategies and need for teacher professional development STAN proceeding of the $45^{\text {th }}$ Annual Conference Pp 217-222.

Obika, K. (2005). Effect of inquiry based method of teaching in Students achievement in Home economics. Unpublished article. F.C.E (T), Asaba.

Retting, K and Canady, M (1996) Inquiry Based teaching. London:Oxford Press. 
